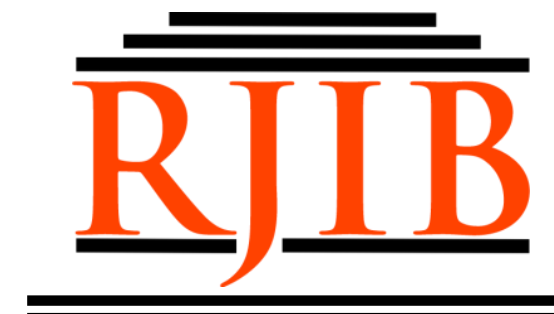

RETORIKA: Jurnal Ilmu Bahasa

Vol. 7, No. 1 April 2021, Page 43-49

P-ISSN: 2406-9019

E-ISSN: 2443-0668

Available Online at https://ejournal.warmadewa.ac.id/index.php/jret

\title{
Interreligious Tolerance in Warganet Condolence- expressions on Passing of B.J. Habibie: Anthropolinguistic Study
}

\author{
Laily Rahmatika*, Agus Budi Wahyudi, Gallant Karunia Assidik \\ Universitas Muhammadiyah Surakarta \\ Lailyrahmatika20@gmail.com,Agus.B.Wahyudi@ums.ac.id,gka215@ums.ac.id
}

\begin{tabular}{|l|}
\hline \multicolumn{1}{|c|}{ Published: 30/04/2021 } \\
\hline How to cite (in APA style): \\
Rahmatika, L., Wahyudi, A. B., \& Assidik, G. K. (2021). Interreligious Tolerance in Warganet Condolence expressions on \\
$\begin{array}{l}\text { Passing of B.J. Habibie: Anthropolinguistic Study. Retorika: Jurnal Ilmu Bahasa, 7(1), 43-49. doi: } \\
\text { https://doi.org/10.22225/jr.7.1.2481.43-49 }\end{array}$ \\
\hline
\end{tabular}

Abstract- The passing of B.J. Habibie is identified as a form of utterance about the existence of interreligious tolerance in Indonesia. Interreligious is intersected with each other in upholding the value of tolerance as manifestation of a sense of Bhineka Tunggal Ika. The research aims to identify the value of tolerance based on potential diversities among interreligious in condolence-expressions. This type of research is a qualitative descriptive study. Data are from Warganet expressions which contain tolerance value. Collecting data uses purposive sampling technique. Data sources are taken from Warganet expressions on Twitter and Instagram. Analyzing data method uses distribution method with markup reading techniques and the equivalent method with referential equivalence technique that refers to the meaning outside of language. The result of this research is that interreligious tolerance is contained in the condolence-expressions in the form of expressions of religious, affection and kinship, and general.

Keywords: Condolence-expressions, Interreligious tolerance, Potential Diversities, Passing of B.J. Habibie, Social media

\section{INTRODUCTION}

Indonesia is known as the catchword of Bhineka Tunggal Ika, which means 'different, but it is still one' as a multicultural country which is well-heeled in ethnicity, culture, language, and religion (Huda \& Filla, 2019). The complex diversity including various religions with various sects, and various religious movements in Indonesia is due to the differences in religious principles.

Indonesia's diversity has the potential for conflict. The background of multicultural state conflicts are religion, culture, language, economy, and politics that cannot be avoided
(Rasimin, 2016). Multicultural conflicts are caused by lack of tolerance among interreligious. Various cases of intolerance are from religion that often occurs. The cases of intolerance occurred in Indonesia made pluralism and tolerance among interreligious fade due to the issues of radicalization, terrorism, and Islamic phobia. For example, blasphemy religion case experienced by Ahok as the Governor of DKI Jakarta during a speech in visiting Pulau Pramuka, Kepulauan Seribu on September $27^{\text {th }}$ 2016, he was deemed insulted religion through his comment in Surah Al-Maidah verse 51 (Damayanti, 2018). In addition, intolerance case 
in culture occurred in Solo with act of beating and vandalism carried out by a group in the "Midodareni (Tarnish Diversity)" (Kurniati, 2020).

The effort to reduce intolerance cases in Indonesia are carried out by developing behavior of society that contains interreligious tolerance. For example, cultivating habit of respect in differences is instilled, so the life is harmonious, safe, and peaceful. One of them is by implementing an attitude of religious tolerance which is reflected in condolence-expressions. The tolerant attitude of Indonesia is identified through Warganet as evidence by the passing of B.J. Habibie.

The passing of B.J. Habibie on September $11^{\text {th }} 2019$ invited many responses from Warganet, both Indonesian and other countries to express their condolences on passing of a figure known as the Father of Indonesian Technology. The event was reported at Kompascom states that the passing of B.J. Habibie became a trending topic on Twitter with the phrase "Goodbye Eyang Habibie" (Puspita, 2019).

Warganet response on passing of B.J. Habibie in social media has fostered tolerance among interreligious from all societies from state officials, religious leaders, celebrities, even societies. Tolerance is a human attitude or behavior that does not deviate from the rules where everyone values in every action of others (Rasimin, 2016). In fact, social media not only has a negative impact on Warganet, but also a positive attitude can be seen from the condolence-expressions given by Warganet. These expressions reflect the existence of various religions to pay his last respect to B.J. Habibie.

The expressions of Warganet that is studied antropolinguistically has a network of problems parallel to the various studies that have been conducted. There is an element of innovation namely the successful identification of potential expressions through the mass media as a means of interreligious tolerance in social and culture life. As it is understood, anthropology is the study of humans and cultures. The Expression of Warganet as a fact of language use in an interesting culture is studied. In this study, the authors apply Duranti's (2001) theory as a basic for analysis. The anthropolinguistics concept according to Duranti (2001) includes performance, indexicality, and participation.

(1) Performance is language use as a reflection of a speaker's mind that cannot be understood separately. According to
Hymes, performance is not mechanical or inferior in nature, but performance is something that is creative, conscious, studied, even provides inspiration from ordinary conversations or events.

(2) Indexicality is a sign that connects the real existential (not interpretation) which requires reaction and attention. In social life, the index includes signs, dress code, dialect, table manner that shows and creates a certain social identity.

(3) Participation occurs in situations that require speech situations such as birthday party, family event, events requiring speech events such as conversations, interviews, dialogues, and speech act in the from of greetings, apology, question, and introduction.

In this study, anthropolinguistics concept of (Duranti, 2001) which is used to analyze the participation in which the speech event namely the passing of B.J. Habibie made Warganet utter various expressions of prayer and praise.

Language variations classified based on profession, customs, family relationships, government objective (Buruadi, 2013). Research on anthropolinguistics study conducted by (Prihadi, 2015) shows that in terms of linguistics and culture in village Yogyakarta, there are 17 types of motivation and toponym goals, 22 kinds of nuance domains of royal life in the main reason for village motivation and goals.

Sariah's research (2018) on the study of anthropology of Indonesia proverbs contain the values of national character. Noortyani (2017) studies Dayak mantras which result in the form of self-protection spells, antidote spells, spells to catch fish, spells to ask for offerings, spells for farming, spells to obey customary law, spells to purify oneself, a spell to ward off bad luck, and a spell to ward off rain.

The problem studied by authors can be formulated as a problem, namely: How is interreligious tolerance based on the potential diversities continued in the condolenceexpressions on the passing of B.J. Habibie? The research aims to identify the value of tolerance based on potential diversities among interreligious in condolence-expressions.

\section{METHODS}

This research is descriptive qualitative. The object of research regarding tolerance is based on the potential diversities in Warganet condolences on the passing of B.J. Habibie on 
social media. The form of data is in condolenceexpressions from Warganet. Data sources are taken from Twitter and Instagram with various hastags such as \#Habibie \#RIPBJHabibie \#RIPHabibie \#Habibiewafat \#RIPBapakTeknologiIndonesia

\#Habibieberpulang \#Indonesiaberduka \#SelamatJalanPakHabibie.

This expression has the same form which contains tolerance and diversity. Data collection uses purposive sampling technique. Analyzing data method uses distribution method with markup reading techniques and the equivalent method with referential equivalence techniques that refer to the meaning outside of language (Sudaryanto, 2015). The presentation of the result of data analysis is an informal form of descriptions.

\section{RESULT AND DISCUSSION Interreligious Tolerance Contained in Condolence-expressions}

Indonesian societies are adherents of

multi-religions. Religion is embraced, for example, Islam, Catholicism, Christianity, Hinduism, and Buddhism. Interreligious tolerance is a principle of concord and harmony in carrying out dynamic social relation between individuals and groups in social life. This tolerance is reflected on the passing of B.J. Habibie. Various religious communities express their condolences as a form of the last utterance in the form of expressions which is embraced as follows:

\section{The Condolence-expressions Interreligious}

The condolence-expressions interreligious contain values of tolerance includes religious, affection and kinship, and general.

\section{Religious}

Religious is a system of belief, value, and law that apply in spiritual expressions (Yatun, 2015) The form of religiosity in the term of life does not only occur in religious rituals, but also it is driven by supernatural forces in the activities carried (Muhyani, 2012).

Tabel 1

The condolence-expressions interreligious

\begin{tabular}{|c|c|c|c|}
\hline No & Expression & Meaning & Tolerance Value \\
\hline 1 & $\begin{array}{l}\text { Inna lillahi wa inna illayhi rajioun. Saddened to } \\
\text { hear of the passing of Pak Habibie, who was the } \\
3^{\text {rd }} \text { President of Indonesia. My Allah forgives Pak } \\
\text { Habibie any mistakes in life and grant him Jannat- } \\
\text { ul-Firdaus. Al Fatihah }\end{array}$ & $\begin{array}{l}\text { Prayers chanted for } \\
\text { B.J. Habibie to be } \\
\text { given forgiveness } \\
\text { and God's paradise. }\end{array}$ & $\begin{array}{l}\text { Respect the beliefs of } \\
\text { others }\end{array}$ \\
\hline 2 & $\begin{array}{l}\text { Innalillahi wa innailaihi rajiun. Hopefully your } \\
\text { late bapak B.J. Habibie husnul khatimah and get } \\
\text { the best in the sight of Allah SWT. Amin ya rabbal } \\
\text { alamin. Al-Fatihah }\end{array}$ & $\begin{array}{l}\text { Praise prayer for } \\
\text { everything is done } \\
\text { by B.J. Hbaibie in } \\
\text { the world can take } \\
\text { him to the heaven } \\
\text { realm. }\end{array}$ & $\begin{array}{l}\text { Respect the beliefs of } \\
\text { others }\end{array}$ \\
\hline 3 & $\begin{array}{l}\text { Today Indonesian nation has lost one of its best } \\
\text { son. Condolences frim the bottom of my heart for } \\
\text { the passing of the } 3^{\text {rd }} \text { President of the Republic } \\
\text { Indonesia Prof. B. J. Hbaibie. May God provide } \\
\text { the best place for him. }\end{array}$ & $\begin{array}{l}\text { A prayer to God, } \\
\text { given a proper place } \\
\text { at the end of his life. }\end{array}$ & $\begin{array}{l}\text { Respect the beliefs of } \\
\text { others }\end{array}$ \\
\hline 4 & $\begin{array}{l}\text { Om swargantu, moksantu, sunyantu, murcantu. } \\
\text { Om ksama sampurnaya namah swaha. Semoga } \\
\text { amor ring acintya-(May the spirit of the deceased } \\
\text { find heaven. Clung to you, attains silence without } \\
\text { suffering. May be united in supreme divinity) }\end{array}$ & $\begin{array}{l}\text { Pray for his spirit } \\
\text { will be given a place } \\
\text { in heaven without } \\
\text { feeling torment, } \\
\text { suffering, and } \\
\text { returning to the holy } \\
\text { realm. }\end{array}$ & $\begin{array}{l}\text { Respect the beliefs of } \\
\text { others }\end{array}$ \\
\hline
\end{tabular}

The data in expressions (1), (2), (3), and (4) are the value of tolerance in respecting the beliefs of others related to God. This expression reflects the religiosity marked by the use of the words 'Jannat-ul-Firdaus', 'innalillahi wainnailaihi rojiun', 'the best place', and 'om swargantu, moksantu, sunyantu, murcantu'. The value contained in this expression contains chanting prayers to be given a place of heaven. Indonesian societies do have a high tolerance for death events. The value of tolerance is traced through condolence-expressions with religious 
values.

This value of tolerance is depicted in the passing of B.J. Habibie. Tolerance in respecting the beliefs of others is reflected in the above as an expression where everyone has the right freedom to express something based on their beliefs. The sense of tolerance among interreligious is seen from the diversity of language in the expressions of grief given.

The use of the word 'Jannah' in data (1) is the concept of paradise for Islam. According to Juhaeriah in (Hamka 2017) heaven is according to the level of Firdaws, 'And, Na'im, Ma'wa, Dar as-Salam, Dar al-Muqamah, Al-Muqqamu alAmin, and Khuldi. The Koran illustrates heaven as a cool garden with luxury, shady trees and free from storms (Mansyur, 2018).

Data (2) innalillahi wa inna ilaihi rojiuun' is used by Muslims when someone gets a disaster, natural disaster, or dies. The meaning of the phrase is 'truly we belong to Allah and will definitely return to Him'. A phrase which is spoken when someone dies. While Husnul Khatimah has an expression of condolences which means 'to die in the best of circumstances'.

Ibnu Qoyyum's article in the book Ar-Ruh states the surah al-Fatihah and verses in the holy Koran as a form of reward for people who have died (Anam, 2015). According to (Nasution, 2018), the purpose of giving al-Fatihah to the deceased is as follows: (1) Respect for ta'zhim and retribution for the kindness of the deceased. (2) The provision of recitation of surah al-Fatihah can enlarge the grave. (3) As a prayer for the deceased.

The best place in the data (3) according to some religious adherents as a resting place afterlife. Christianity interprets the ultimate goal of life as heaven or the kingdom of heaven.

Buddhism in its book, 'God is something that is not born, not incarnated, not created and absolute'.

The Hindu heaven on data (4) in Geguritan Atma Prasanga is 'such a beautiful place and colorful flower gardens, full of precious jewels, fragrances. The place of the seat, very beautiful nymphs, offered food, and jewelry that is pretty and beautiful, is called padmasana, (Asmariani, Suarka, \& Duija, 2019).

In this case, the religious expression contains the keyword prayer with the value of tolerance respects the beliefs of others on the passing of B.J. Habie in social media which has become a culture among Warganet by saying 'innalillahi wainna ilaihi rojiu'un', 'rest in peace', 'given the best place'. The giving of greeting is contextually known in Indonesian culture as takziah which is visiting a family mourning as the last respects of the person who has died. This culture is carried over in the realm of social media where everyone can give condolenceexpressions to people who have died as a medium to represent feelings of loss. Culture occured in social media is related to the interpretation of Warganet in seeing reality to be addressed with beliefs. The culture is formed in the form of things in starting from posting photos of that person by providing captions and providing comments on other people's or media's accounts.

\section{Affection and Kinship}

Affection is an expression of encouraging public morale to care (Prasetyo, 2020). This expression emphasizes the strengths of a character in establishing a relationship with a love story and building an Islamic family. The example of expressions below.

Tabel 2

The condolence-expressions interreligious

\begin{tabular}{|c|c|c|c|c|}
\hline No & Expression & Meaning & \multicolumn{2}{|c|}{ Tolerance Value } \\
\hline 5 & $\begin{array}{l}\text { My sincerest condolences to Eyang } \\
\text { Habibie, I can't imagine how excited } \\
\text { him to meet Ibu Ainun right now. }\end{array}$ & $\begin{array}{l}\text { A continued meeting of } \\
\text { B.J. Habibie's love } \\
\text { story in afterlife. }\end{array}$ & $\begin{array}{l}\text { Understand } \\
\text { other }\end{array}$ & each \\
\hline 6 & $\begin{array}{l}\text { You will be together again with your } \\
\text { beautiful wife, in Jannah. Rest in Peace, } \\
\text { Sir. }\end{array}$ & $\begin{array}{l}\text { A hope reunited with } \\
\text { his beloved lover, Ibu } \\
\text { Ainun, to enjoy heaven } \\
\text { together. }\end{array}$ & $\begin{array}{l}\text { Understand } \\
\text { other }\end{array}$ & each \\
\hline 7 & $\begin{array}{l}\text { Goodbye the 3rd President of the } \\
\text { Republic of Indonesia Prof. DR. (HC). } \\
\text { Ing. Dr. Sc. Mult. Bachruddin Jusuf } \\
\text { Habibie Welcome to meet your } \\
\text { Javanese sugar, your genius and loyalty } \\
\text { to your eternal lover will become a } \\
\text { memory. }\end{array}$ & $\begin{array}{l}\text { A love story of life and } \\
\text { death as a memory in } \\
\text { the world. }\end{array}$ & $\begin{array}{l}\text { Understand } \\
\text { other }\end{array}$ & each \\
\hline
\end{tabular}


\begin{tabular}{l|l}
8 & Habibie is loyal to his partner, both in
\end{tabular} times of trouble and joy. Together lead each other on the right path. Very inspiring. Should be used as a role model for the deceased

The data in expressions (5) (6) and (7) are the value of tolerance with mutual understanding of a love story relationship that will meet a lover for life and death in his heavenly world. This expression reflects affection and kinship which is characterized by the use of 'how excited him to meet Ibu Ainun', 'be together again with your beautiful wife' and 'Welcome to meet your Javanese sugar, your genius and your loyalty'. The value contained in this expression is a continuation of a journey of a love story in the same realm namely afterlife. Data (8) describes a person who is considered as role model for the nation in establishing a relationship. This attitude shows the value of tolerance of awareness and honesty expressed by the Warganet with the marker 'Should be used as a role model'. The value of tolerance with awareness and honesty is shown by Warganet from different religious backgrounds explaining how the love story of B.J. Habibie lived his life.

In a relationship, loyalty is the key in a relationship to keep one heart promise not to betray (Choznah, 2019). B.J. Habibie' affection is always a memory. Loyalty towards her lover is

Life in living a
relationship story in a
bond which accepts
each other's advantages
and weaknesses.

reflected in her relationship with each other for more than 40 years. B.J. Habibie 's attitude who is exemplary. For example, his sincere love for sacrificing for the Indonesian nation and for the family is in the form of determination and hard work in science and technology (Astuti, 2016).

The phrases contained in the family are marked with the words 'Eyang' and 'Sir'. The word is in Indonesian culture as a reference to someone in the closest scope. 'Eyang' is a grandfather and 'Sir' is a father. In a culture with affection and kinship, this word is a calling in the family. This culture is carried away in the media where Warganet think B.J. Habibie is a role model in the family in a relationship with a love story. Meanwhile, cultured people actually have manners, people who die are considered as civility that the dead person will be reunited with his partner in heaven.

\section{General}

General is in the form of expressions of giving awards and things that give B.J. Habibie as a character. Here are common expressions of expression.

Tabel 3

The condolence-expressions interreligious

\begin{tabular}{|c|c|c|c|}
\hline No & Expression & Meaning & Tolerance Value \\
\hline 9 & $\begin{array}{l}\text { Danke, Mr. President This country often } \\
\text { takes for granted the very thing that } \\
\text { most deserves our gratitude. We come } \\
\text { not to mourn, but to celebrate you. thank } \\
\text { you for freedom always }\end{array}$ & $\begin{array}{l}\text { An appreciation for the } \\
\text { figure B.J. Habibie by } \\
\text { opening up freedom } \\
\text { during his reign }\end{array}$ & $\begin{array}{l}\text { Giving freedom and } \\
\text { Independence }\end{array}$ \\
\hline 10 & $\begin{array}{l}\text { My deepest condolences on the passing } \\
\text { away on the } 3^{\text {rd }} \text { President of the } \\
\text { Republic Indonesia, Bapak B.J. } \\
\text { Habibie. We have lost a true statesman } \\
\text {, an intelligent, always optimistic, and } \\
\text { positive figure. }\end{array}$ & $\begin{array}{l}\text { Losing a smart figure } \\
\text { who has always been a } \\
\text { model figure for the } \\
\text { nation's children }\end{array}$ & $\begin{array}{l}\text { Awareness } \\
\text { Honesty }\end{array}$ \\
\hline 11 & $\begin{array}{l}\text { \{\#Habibie\} is.... a scientist who believes } \\
\text { that without love intelligence is } \\
\text { dangerous. He is truly a role model for } \\
\text { all of the nation's children...surely } \\
\text { Indonesia has lost one of its best son }\end{array}$ & $\begin{array}{l}\text { The balance between } \\
\text { intelligence and love is } \\
\text { the most important } \\
\text { thing in happiness } \\
\text { which makes him a role } \\
\text { model in the lives of the } \\
\text { nation's children. }\end{array}$ & $\begin{array}{l}\text { Agree } \\
\text { disagreement }\end{array}$ \\
\hline 12 & $\begin{array}{l}\text { Condolences for the death of the 3rd } \\
\text { President of the Republic of Indonesia } \\
\text { Bachruddin Yusuf Habibie Eyang has } \\
\text { left, but his work is eternal. Thank you }\end{array}$ & $\begin{array}{l}\text { A timeless real } \\
\text { contribution to emulate. }\end{array}$ & $\begin{array}{l}\text { Awareness } \\
\text { Honesty }\end{array}$ \\
\hline
\end{tabular}


The data in the expression (9) is the value of tolerance by giving freedom and independence to the system during the reign of B.J. Habibie. This expression is a general expression that reflects gratitude for the freedom that has been given to the Indonesian people which is marked with "thank you for freedom always". Value recognizes the rights of others in expression (10) as a form of awareness and honesty. As it was losing a smart figure who has always been a model figure for the nation's children which was marked in 'a true statesman, an intelligent, always optimistic, and positive figure. In (11) agree in disagreement is defined as agreeing in the existence of differences in life which is marked "a scientist who believes that without love intelligence is dangerous". This expression shows religious tolerance in the form of agree in disagreement when only B.J. Habibie who believes that without intelligence, love is dangerous. The belief arises that intelligence and love are one unit.

The value of tolerance in (12) is awareness and honesty for services and contributions to the Indonesian nation with the marker 'thank you for connecting the islands in the archipelago'. This expression as a matter of respect for the people can be connected to one another with their intelligence in combining islands with different cultural, racial and ethnic backgrounds into a unity. This tolerance reflects the depiction of the figure of B.J. Habibie with his intelligence who creates an achievement and major change in his era where it is believed among interreligious to be the driving force of change.

B.J. Habibie becomes an inspiration for the nation's children due to his exemplary, integrity, kindness, and a figure as a technology scientist and a scientist who holds a high commitment and willingness for an advanced of Indonesia (Astuti, 2016). A big contribution was given to Indonesia in the field of aerospace technology. He also built bridges in bilateral relations and cooperation between Indonesia and Germany in the fields of education, research, and science. (Pratomo, 2019) achievement of B.J. Habibie is in the field of technology for Indonesia as follows: (1) The discovery of new theories: wing crack theory in the aircraft industry; (2) Strategic industry pioneers: manufacture of the Gatotkaca N250 aircraft; (3) Economic recovery: strengthening the value of the rupiah; and (4) the President of
Indonesia.

This general expression of the advantages of a character with his intelligence and contributions, and services reflects a culture for Warganet to express positive behaviors in their lives. In religion, expressing the kindness of that person will be a charity for the person who died, because those positive behaviors will bring help afterlife.

The expressions are formed in the media which is now a culture that Warganet continue to use in building a spirit of tolerance towards something that is different from a religious background. This culture is always attached such the passing of Ashraf Sinclair, Eyang Sudijiatmi Notomihardjo, Didi Kempot, and Glenn Fredly.

\section{CONCLUSION}

Based on the result and discussion, it can be concluded that the expression form of religious, affection and kinship, and general. The form of these expressions is a potential diversities for tolerance among interreligious in Indonesia.

\section{REFERENCES}

Anam, A. K. (2015, September). Hadiah Fatihah untuk Orang yang Meninggal Dunia. Ubudiyah.

Asmariani, A. A. R., Suarka, I. N., \& Duija, I. . (2019). Eskatologi dalam Teks Geguritan Atma Prasangsa (Kajian Teks dan Konteks). Jurnal Penelitian Agama Hindu, 3(1), 23-34.

Astuti, R. (2016). Ketauladanan B.J. Habibie Menginspirasi Generasi Muda Bangsa Indonesia. Kompasiana.

Damayanti, A. U. (2018). Jalan Panjang Kasus Penistaan Agama Ahok, dari Al Maidah 51 hingga PK. Okenews.

Duranti, A. (2001). Linguistic Antropology. Cambridge: Cambridge University Press.

Huda, M. T., \& Filla, O. (2019). Media Sosial sebagai Sarana Membangun Kerukunan Pada Komunitas Young Interfaith Peacemaker (YIPC). Religi Jurnal Studi Agama-Agama, 15(1), 28-50.

Kurniati, P. (2020). Fakta Pengeroyokan saat Acara Midodareni di Solo yang Disebut Coreng Kebhinnekaan. Kompas.Com.

Mansyur, S. (2018). Konsep Al-Qur'an tentang Surga. Al Asas, 1(2), 1-13.

Muhyani. (2012). Pengaruh Pengasuhan Orang Tua dan Peran Guru di Sekolah Menurut Persepsi Murid terhadap Kesadaran Religius dan Kesehatan Mental, Jakarta: Kementerian Agama Republik Indonesia Direktorat 
Jenderal Pendidikan Islam Direktorat Pendidikan Tinggi Islam.

Nasution, A. . (2018). Hukum Hadian Al-Fatihah kepada Mayit dalam Perspektif Fiqh Muqaran. Jurnal Madani: Ilmu Pengetahuan, Teknologi, Dan Humaniora, 1(2), 431-449.

Noortyani, J. Z. R. (2017). Antropolinguistik dalam Mantra Dayak Maanyan di Kalimantan Selatan. Jurnal Bahasa, Sastra Dan Pembelajarannya, 7(1), 35-49.

Prasetyo, A. A. (2020). Internalisasi Hadis Kasih Sayang dalam Mewujudkan Social Interest di Era Disrupsi. Jurnal Studi Ilmu-Ilmu AlQur'an Dan Hadis, 21(1), 217-236.

Pratomo, H. B. (2019). 4 Pencapaian Menakjubkan BJ Habibie.

Prihadi. (2015). The Anthroponym System Of Hamlets/Villages In Yogyakarta Special Province (An Antropolinguistic Study). RA Journal of Applied Research, 1(2), 72-85.
Puspita, S. (2019, September). Habibie Meninggal Trending Twitter, Warganet Ucapkan "Selamat Jalan Eyang Habibie. Kompas. Com.

Rasimin. (2016). Toleransi dan Kerukunan Umat Beragama di Masyarakat Randuacir. Interdisciplinary Journal of Communication, 1(1), 99-118.

Sariah. (2018). Nilai-nilai Karakter Bangsa dalam Peribahasa Bahasa Indonesia: Kajian Antropolinguistik. Proc. Balai Bahasa Jawa Barat.

Sudaryanto. (2015). Metode dan Aneka Teknik Analisis Bahasa: Pengantar Penelitian Wahana Kebudayaan secara Linguistis. Yogyakarta: Duta Wacana University Press.

Yatun, S. Y. (2015). Situasi Psikologis Keluarga dalam Mengembangkan Religiusitas Anak pada Keluarga Jawa. Universitas Muhammadiyah Surakarta. 